\title{
Isolation and Screening of Industrially Important Fungi from the Soils of Western Ghats of Agumbe and Koppa, Karnataka, India
}

\author{
Mukunda $\mathrm{S}^{1^{*}}$, Onkarappa $\mathrm{R}^{2}$, Prashith Kekuda T. $\mathbf{R}^{1,2}$ \\ ${ }^{1}$ Department of Microbiology, SRNM National College of Applied Sciences, NES Campus, Shivamogga- \\ 577201, Karnataka, India \\ ${ }^{2}$ Department of Studies and Research in Microbiology, Sahyadri Science College (Autonomous), \\ Shivamogga-577203, Karnataka, India
}

\begin{tabular}{|c|c|}
\hline Abstract & Article Information \\
\hline $\begin{array}{l}\text { The present study is an attempt to isolate the fungi from the unexplored soils } \\
\text { of Western Ghats and screen them for the production of some very important } \\
\text { hydrolytic enzymes such as amylase, cellulose, CMCase, protease, lipase } \\
\text { and pigment production. In this work, more than } 200 \text { fungal isolates were }\end{array}$ & $\begin{array}{ll}\text { Article History: } \\
\text { Received : } 14-10-2012 \\
\text { Revised }: 26-12-2012 \\
\text { Accepted }: 29-12-2012 \\
\end{array}$ \\
\hline $\begin{array}{l}\text { isolated from the forest soil were screened for the production of extracellular } \\
\text { enzymes, identification of the screened isolates and secondary screening for } \\
\text { amylase production was done. A total of } 167 \text { isolates were characterized, in } \\
\text { them some up to species level. Aspergillus, Penicillium, Trichoderma and } \\
\text { Cladosporium were predominated. A total of } 14 \text { isolates were selected for }\end{array}$ & $\begin{array}{l}\text { Keywords: } \\
\text { Western Ghats } \\
\text { Soil } \\
\text { Agumbe } \\
\text { Hydrolytic Enzymes }\end{array}$ \\
\hline 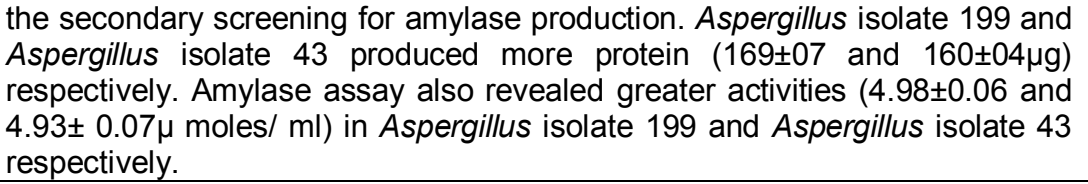 & $\begin{array}{l}{ }^{*} \text { Corresponding Author: } \\
\text { Mukunda S } \\
\text { E-mail: } \\
\text { mukundas_micro@rediffmail.com }\end{array}$ \\
\hline
\end{tabular}

\section{INTRODUCTION}

The role of many enzymes has been known for a long time. Their existence was associated with the history of ancient Greece, where they were using enzymes from microorganisms in bakery, brewing, alcohol production, cheese making etc., (Haki and Rakshith, 2003). Nowadays enzymes are used in large scale in the textile (amylase, cellulose, oxidoreductase); detergents (protease, lipase, cellulose, amylase and oxidoreductase), food (pectinase, protease, cellulose and oxidoreductase); paper (xylanase, oxido-reductase and lipase) and leather (protease and lipase) industries. The major classes of enzyme offering immediate application are the hydrolytic enzymes (Kirk et al., 2002). Among all industrial enzymes, hydrolytic enzymes account for $85 \%$. Microbial enzymes are preferred to those from plants and animal sources because they are cheaper to produce and their enzyme contents are more predictable, controllable and reliable (Oyeleke and Oduwole, 2009) and also because of their broad biochemical diversity, feasibility of mass culture and ease of genetic manipulation. Today, the new potential of using microorganisms as biotechnological sources of industrially relevant enzymes have stimulated renewed interest in the exploration of extracellular enzymatic activity in several microorganisms (Buzzini and Martini, 2002; Gupta et al., 2003; Bakri et al., 2009). Selection of the right organism plays a key role in high yield of desirable enzymes (Satyaprabha et al., 2011). Fungi are microorganisms which are well known for their wide range of novelty of enzymes they produce and enzymes of fungal origin are used in the industrial process for which, amount to billions of dollars of revenue annually (Arunsasi et al., 2010). Due to their diversity, fungi have been recognized as a source of new enzymes with useful and/or novel characteristics (Bakri et al., 2009). Filamentous fungi are 
Mukunda et al.,

particularly interesting due to their easy cultivation, and high production of extracellular enzymes of large industrial potential (Mishra and Dadhich, 2010).

Soil provides a heterogeneous and complex environment for all soil inhabitants. Soil is also known to harbor different microorganisms including diverse group of fungi. Western Ghats are considered as one of the hot spot locations for biodiversity including microbial diversity. Hence the soils from Western Ghats can be a source of fungi of industrial importance. Screening of microorganisms with higher $\alpha-$ amylase activities could therefore, facilitate the discovery of novel amylases suitable to new industrial applications (Gupta et al., 2003). In the present work, we have isolated, characterized and screened the fungal isolates for the production of industrially important enzymes and pigments from soil samples of Agumbe and Koppa of Karnataka, India.

\section{MATERIALS AND METHODS}

\section{Isolation of Fungi}

Soil samples from 6 to 10 inch depth were collected aseptically from 18 different zones of deep forests of Agumbe region and near Jayapura, Koppa using sterile zip lock covers. The soil samples were sieved and processed aseptically and used for the isolation of fungi. The soil samples were inoculated to the Potato dextrose agar (PDA), Sabouraud's dextrose agar (SDA) Potato carrot agar (PCA) and Czapek Dox agar (CZA) by Spread plate technique following serial dilution, Soil direct plating technique, Warcup method and stress technique and incubated at $25^{\circ} \mathrm{C}$ for 3 days. The media were amended with Chloramphenicol to prevent the growth of bacteria (Srinivasan, 2004). The fungal species were grown on the Czapek Dox agar plates, identified based on Cultural and morphological characteristics using standard manuals (McGinnis et al., 1982; Barnette and Hunter, 1972; Malloch, 1981).

\section{Screening for Enzymes and Pigment Production}

\section{Screening for Amylase Production}

Preliminary screening was done by inoculating the fungal isolates on starch agar (containing peptone, $1 \%$; yeast extract, $1 \%$; $\mathrm{KH}_{2} \mathrm{PO}_{4}, 0.5 \%$; agar $2 \%$ and supplemented with $1 \%(\mathrm{w} / \mathrm{v})$ starch (HiMedia) as a carbon source and supplemented with antibacterial antibiotic Chloramphenicol) plate with fungal isolates. After incubation, the plates were flooded with lodine solution (lodine -
Sci. Technol. Arts Res. J., Oct-Dec 2012, 1(4):27-32

$0.2 \mathrm{~g}$, Potassium lodide- $0.4 \mathrm{~g}$, Distilled water$100 \mathrm{ml}$ ), and observed for the clear zone of hydrolysis surrounding the colony (Aneja,1996; Kathiresan and Manivannan, 2006).

\section{Screening for Cellulase Production}

The fungal isolates were inoculated into cellulose media and incubated at $25{ }^{\circ} \mathrm{C}$ for 7 days. The plates were flooded with $0.1 \%$ Congo red solution and observed for zone of clearance (Samira et al, 2011).

\section{Screening for Carboxymethyl Cellulase Production}

The fungal isolates were inoculated in Carboxymethyl cellulose media and incubated at $25^{\circ} \mathrm{C}$ for 7 days. The plates were flooded with $0.1 \%$ congo red solution and observed for zone of clearance (Samira et al., 2011).

\section{Screening for Protease Production}

The fungal isolates were inoculated on Casein agar plates and incubated at $25^{\circ} \mathrm{C}$ for 4 days. After incubation, the plates were observed for the clear zone surrounding the colony (Aneja, 1996).

\section{Screening for Lipase Production}

The fungal isolates were inoculated on mineral medium amended with Tween 80. The formation of opalescence surrounding the fungal colony was recorded as positive for lipase production (Rajan et al., 2011).

\section{Pigment Production}

The isolates producing diffusible extracellular pigments were selected and preserved.

\section{Secondary Screening for Amylase Production by Submerged State Fermentation}

Based on the measurement of zone of clearance around the colony, the 14 fungal isolates belonging to 4 genera were selected for the secondary screening. The cultures were grown in $250 \mathrm{ml}$ Erlenmeyer flask containing 100 $\mathrm{ml}$ of production medium $\left(\mathrm{NH}_{4} \mathrm{NO}_{3}, 1 \% ; \mathrm{KH}_{2} \mathrm{PO}_{4}\right.$, $0.2 \% ; \mathrm{MgSO}_{4} .7 \mathrm{H}_{2} \mathrm{O}, 0.2 \% ; \mathrm{FeSO}_{4} .7 \mathrm{H}_{2} \mathrm{O}, 0.001 \%$ and soluble starch, $2 \%$; pH 6.0) and incubated at $30^{\circ} \mathrm{C}$ for 5 days. After incubation, the cultures were filtered and the culture filtrate was centrifuged at $4000 \mathrm{rpm}$ for 10 minutes and the supernatant was used as crude enzyme (Kundu and Das, 1970).

\section{Protein Estimation}

The protein content of culture filtrate was determined by the Lowry's method, as described by Lowry's (1951) using bovine serum albumin (BSA) as a Standard, absorbance was read at 
$660 \mathrm{~nm}$ using Systronics Spectrophotometer Model 104.

\section{Estimation of Reducing Sugars}

The glucose concentration was determined by DNS method, as described by Miller (1959) using glucose as a standard. The color developed was measured at $540 \mathrm{~nm}$ using Systronics Spectrophotometer Model 104.

\section{Determination of Amylase Activity}

The amylase activity of the crude enzyme was determined using $1 \%$ soluble starch as substrate, prepared in sodium phosphate buffer $(0.1 \mathrm{M}, \mathrm{pH}$ 6.0). The reaction mixture containing $0.5 \mathrm{ml}$ of enzyme and $0.5 \mathrm{ml}$ of substrate (1\% starch) by maintaining a blank containing $0.5 \mathrm{ml}$ of enzyme and $0.5 \mathrm{ml}$ of buffer was incubated at $30^{\circ} \mathrm{C}$ for 15 min in a water bath. The DNS method was followed for the incubated samples and optical density was read at $540 \mathrm{~nm}$ against blank. A standard curve of glucose $(1 \mathrm{mg} / \mathrm{ml})$ was developed under identical conditions to determine the reducing sugars formed. The enzymatic activity of filtrate was expressed as Unit per $\mathrm{ml}$ $(\mathrm{U} / \mathrm{ml})$, which is defined as the amount of enzyme which liberates $1 \mu \mathrm{mol}$ of reducing sugar per $\mathrm{ml}$ per minute under assay conditions.

\section{RESULTS AND DISCUSSION}

More than 200 fungal isolate were isolated from soil by different techniques and 167 isolates were characterized based on colony morphology and microscopic mount of the isolates. About 35 isolates were not identified. The isolates belonged to the genera Aspergillus ( $A$. niger, $A$. flavus, $A$. terreus, $A$. fumegatus, $A$. nidulans, $A$. versicolor), Penicillium, Trichoderma, Fusarium, Cladosporium, Pacillomyces, Gliocladium, Scopulariopsis, Verticillium, Curvularia, Alternaria, Rhizopus and Mucor. Some Aspergillus and Penicillium isolates were characterized only up to Genus level. The members of Aspergillus, Penicillium and Trichoderma were dominant among fungal isolates. Table 1 depicts production of hydrolytic enzymes and pigment by the isolated fungi.

More than $85 \%$ of the isolates showed the amylase production, followed by Cellulase $(58 \%)$, CMCase $(64 \%)$, protease $(36 \%)$, lipase $(37 \%)$ and water soluble pigments $(40 \%)$. Of these starch hydrolysis positive isolates, based on the extent of zone of hydrolysis formed on starch agar plates, 14 isolates belonging to different genera were selected for secondary screening by submerged fermentation. The amount of extracellular protein synthesized and the specific amylase activity of the isolates is shown in the table 2.

In the secondary screening, the production of extracellular proteins was found to be more in Aspergillus isolates compared to the isolates of other genera. In Aspergillus isolates, isolate No. 199 and 43 produced highest concentrations of protein. The Specific activities of amylases of respective isolates were also calculated. The Aspergillus isolates (Number 199 and 43) showed more specific activity.

Bankar et al. (2012) worked on the isolation and screening of forest soil of Bhadra Wild Life Sanctury, for potent amylolytic fungi. The isolated fungi were mainly belonged to Penicillium chrysogenum, Aspergillus candidus, Aspergillus fumigatus. It was found that Penicillium $s p$ showed more amylase activity for both $3^{\text {rd }}$ day and $7^{\text {th }}$ day incubation. Penicillium chrysogenum was found to produce more soluble crude protein. Friedrich et al. (1999) isolated of more than 300 fungal isolates from air and screened for keratinase production. Moallaei et al. (2006) isolated a total of 357 fungal colonies including 13 genera with 11 species Anixiopsis stercoraria (16.24\%), Arthroderma cuniculi (12.04\%), Reniospora flavissima (9.24\%), Fusarium oxysporum (9.24\%), Aspergillus flavus (8.68\%), Chrysosporium keratinophilum (8.40\%), Trichophyton vanbreuseghemii (7.84\%), and other fungi $(37.56 \%)$, and reported that nonkeratinophilic fungi were prevalent in the forest soil. Arunsasi et al. (2010), isolated 15 fungal species namely, A. fumigatus, $A$. oryzae, A.niger, A. flavus, $A$. nidulance, A. sulphurus, $A$. terreus, Trichoderma vessei, T. viridae, Penicillium citrinum, $P$. oxalicum, Fusarium moniliformis, F.oxalicum, F. oxysporum, Rhizopus oryzae from the soil samples of the coastal region of Neendakara, along the West cost of Kerala, India and screened them for amylase production and found that $A$. flavus produced maximum zone of hydrolysis on Starch agar media. Sathyaprabha et al. (2011) reported the isolation of fungi namely, Aspergillus fumigatus, Aspergillus versicolor, Aspergillus nidulans and Aspergillus niger from soil samples obtained from crude petroleum oil contaminated soil. They screened the isolates for amylase and cellulose production. Kathiresan and Manivannan (2006) isolated Strains of Penicillium sp. from the coastal soil of a mangrove habitat and later identified as $P$. fellutanum and screened for amylase production. Tiwari (2007) isolated a fungus from soil identified as $P$. rugulosum and screened it for amylase 
Table 1: Enzyme and pigment production by fungal isolates.

\begin{tabular}{|c|c|c|c|c|c|c|c|}
\hline $\begin{array}{l}\text { SI. } \\
\text { No. }\end{array}$ & Isolate & $\begin{array}{c}\text { Amylase } \\
\text { production }\end{array}$ & $\begin{array}{c}\text { Cellulase } \\
\text { production }\end{array}$ & $\begin{array}{c}\text { CMCase } \\
\text { production }\end{array}$ & $\begin{array}{c}\text { Protease } \\
\text { production }\end{array}$ & $\begin{array}{c}\text { Lipase } \\
\text { production }\end{array}$ & $\begin{array}{c}\text { Pigment } \\
\text { production }\end{array}$ \\
\hline 1. & Aspergillus niger (19)* & +++ & + & + & + & + & - \\
\hline 2. & A. flavus $(13)^{*}$ & +++ & - & + & - & + & - \\
\hline 3. & A. terreus $(14)^{*}$ & + & - & - & - & - & +++ \\
\hline 4. & A. fumigatus $(4)^{*}$ & + & + & + & - & + & - \\
\hline 5. & A. nidulans(3) & ++ & - & - & - & + & - \\
\hline 6. & Aspergillus isolate $16^{* *}$ & ++++ & - & - & ++ & + & - \\
\hline 7. & Aspergillus isolate $25^{* *}$ & ++++ & ++ & +++ & + & + & - \\
\hline 8. & Aspergillus isolate $43^{* *}$ & +++++ & + & + & + & - & ++ \\
\hline 9. & Aspergillus isolate $122^{* *}$ & ++++ & - & ++ & + & + & +++ \\
\hline 10. & Aspergillus isolate $160^{* *}$ & +++ & - & - & - & - & ++ \\
\hline 11. & Aspergillus isolate $199^{* *}$ & +++++ & - & - & + & + & - \\
\hline 12. & Penicillium notatum (6)* & +++ & + & + & + & + & + \\
\hline 13. & Penicillium isolate $73^{* *}$ & +++ & + & ++ & + & - & - \\
\hline 14. & Penicillium isolate $33^{* *}$ & ++ & + & ++ & - & - & ++ \\
\hline 15. & Trichoderma sp.(24)** & ++ & +++ & +++ & - & - & +++ \\
\hline 16. & Fusarium $s p .(12)^{* *}$ & +++ & + & ++ & - & - & ++ \\
\hline 17. & Cladosporium sp.(13)** & - & + & + & + & - & - \\
\hline 18. & Pacillomyces sp.(6)** & + & + & + & - & - & - \\
\hline 19. & Gliocladium sp.(3)** & - & + & + & - & - & - \\
\hline 20. & Scopulariopsis sp.(4)** & - & - & - & - & - & - \\
\hline 21. & Verticillium sp.(4) ${ }^{* *}$ & + & + & - & - & - & - \\
\hline 22. & Curvularia sp.(6)** & + & + & + & - & - & + \\
\hline 23. & Alternaria $s p .(3)^{* *}$ & + & - & - & - & - & - \\
\hline 24. & Rhizopus sp.(17) ${ }^{* *}$ & ++ & - & - & + & + & - \\
\hline 25. & Mucor sp.(8)** & + & - & - & - & - & - \\
\hline
\end{tabular}

*The numbers within the bracket corresponds to number of isolates obtained.

** Fungal isolates characterized up to genus level.

The sign $(+)$ indicates the positive screening test and $(-)$ indicates a negative screening test.

The number of $(+)$ mark ranging from $1+$ to $5+$ indicates the extent of hydrolysis as indicated by the zone of clearation surrounding colony. 
Table 2: Protein content of culture filtrate and specific activity of crude amylase.

\begin{tabular}{|c|c|c|c|}
\hline $\begin{array}{l}\text { SI. } \\
\text { No. }\end{array}$ & Name of the isolate & $\begin{array}{c}\text { Extracellular } \\
\text { protein } \\
\mu \mathrm{gs} / \mathrm{ml}^{*}\end{array}$ & $\begin{array}{c}\text { Specific } \\
\text { Activity } \\
(\mu \mathrm{mol} / \mathrm{ml} / \mathrm{Min})^{*}\end{array}$ \\
\hline 01. & Aspergillus niger & $139 \pm 10$ & $4.08 \pm 0.09$ \\
\hline 02. & A. terreus & $112 \pm 07$ & $2.91 \pm 0.10$ \\
\hline 03. & A. flavus & $119 \pm 09$ & $3.02 \pm 0.12$ \\
\hline 04. & A. oryzae & $102 \pm 08$ & $3.27 \pm 0.07$ \\
\hline 05. & A. versicolor & $141 \pm 09$ & $3.28 \pm 0.13$ \\
\hline 06. & A. fumigatus & $123 \pm 05$ & $3.19 \pm 0.16$ \\
\hline 07. & Aspergillus isolate 16 & $144 \pm 12$ & $3.52 \pm 0.05$ \\
\hline 08. & Aspergillus isolate 25 & $132 \pm 07$ & $3.30 \pm 0.11$ \\
\hline 09. & Aspergillus isolate 43 & $160 \pm 04$ & $4.93 \pm 0.07$ \\
\hline 10. & Aspergillus isolate 199 & $169 \pm 07$ & $4.98 \pm 0.06$ \\
\hline 11. & Penicillium notatum & $78 \pm 06$ & $2.01 \pm 0.03$ \\
\hline 12. & Penicillium isolate 73 & $86 \pm 11$ & $2.95 \pm 0.06$ \\
\hline 13. & Fusarium sp. & $75 \pm 09$ & $2.92 \pm 0.10$ \\
\hline 14. & Rhizopus sp & $58 \pm 04$ & $2.12 \pm 0.08$ \\
\hline
\end{tabular}

*Mean of three replicates, \pm Standard deviation (SD)

production. Pothiraj et al. (2006) isolated Rhizopus stolonifer, Aspergillus niger and Aspergillus terreus by primary selection from a naturally contaminated cassava waste by serial dilution and pour plate technique and reported the production of cellulase by solid state fermentation. Gautam et al. (2010) studied on the isolation and screening of cellulolytic fungi from municipal solid waste. Out of 20 fungal culture isolates from environmental sources including 8 different zones, 16 fungi were found to passes cellulose degrading ability. Cellulolytic fungi belonging to Aspergillus funmigatus, Trichoderma sp.I and Chaetomium sp. Results obtained during this study clearly indicate that cellulase activity of Aspergillus fumigatus and Trichoderna sp. 1 were found relatively towards the higher side and $A$. niger, A. flavus, $A$. nidulans, Alernaria sp., Penicillium sp. moderate range while Fusarium sp., Humicola sp. and Torula sp. showed low cellulase activity. Damisa et al. (2011) reported the isolation of a native Aspergillus niger strain from the soil samples taken from six locations in Zaria. The samples were collected from rice growing field, compost soils, street soil, fallow farm land, flower beds and maize farm. They screened the cellulolytic efficacy of the isolate on modified Mondels mineral agar. However, screening of microorganisms with higher $\alpha$ - amylase activities could therefore, facilitate the discovery of novel amylases suitable to new industrial applications.

\section{CONCLUSION}

The present study showed that the forest soils of Western Ghats can be a very good source of industrially important enzymes. The secondary screening for the production of amylase was also done for 14 selected isolates. Among the fungal isolates, Aspergillus, Penicillium, Trichoderma and Cladosporium predominated. In the present study, the screening for only the main groups of hydrolytic enzyme producers was made. The vast microbial biodiversity of the Western Ghats is yet to be exploited so that the indigenous soils can be screened for the isolation of other novel fungi with the ability of production of some other important enzymes, antibiotics and other bioactive compounds. Since each application of enzymes in industry requires different specificities, the hydrolytic enzymes with different properties have to be isolated. Further studies with regard to the optimization of production parameters and the catalytic properties are required to be done. 


\section{ACKNOWLEDGMENTS}

The authors are thankful to The Principal, SRNM National College of Applied Sciences, The Management, National Education Society, Shivamogga, Sri. Ramachandra K, Jayapura, Koppa for their support to carry out the work.

\section{REFERENCES}

Aneja, K.R. (1996). Experiments in Microbiology, Plant Pathology, Tissue Culture \& Mushroom Cultivation. $2^{\text {nd }}$ Ed. Wishwa Prakashan, New Delhi, Pp. 451.

Arunsasi., Kani, M., Panneerselvam, A., Jegadeesh, G., Muthu, K and Kumar, M.R. (2010). Optimizing the conditions of $\alpha$ - amylase by an Estuarine strain of Aspergillus spp. African Journal of Microbiology Research 4 (8): 581-586.

Bakri, Y., Mangali, M and Thonart, P. (2009). Isolation and Identification of a New Fungal Strain for Amylase Biosynthesis. Polish Journal of Microbiology 58(3):269-273.

Banakar, S.P., Thippeswamy, B., Thirumalesh, B.V and Naveenkumar, K.J. (2012). Isolation, production and partial purification of fungal amylase from forest soils of Bhadra Wildlife Sanctury, Western Ghats. Inventi Rapid: Pharmacy, Biotechnology and Microbiology 3:1-7.

Barnett, H.L and Hunter, B.B. (1992). Illustrated genera of imperfect fungi. $3^{\text {rd }}$ Edition. Burgess publishing company, Minnessota. Pp-241.

Buzzini, P and Martini, A. (2002). Extracellular enzymatic activity profiles in yeast and cassava waste dumpsite in Minna, Niger State, Nigeria. African Journal of Microbiology Research 3 (4): 143-146.

Damisa, D., Ameh, J.B and Egbe, N.E.L. (2011). Cellulase Production by native Aspergillus niger obtained from soil environments. Fermentation Technology and Bioengineering 1: 62-70.

Friedrich, J., Gradisar, H., Mandin, D and Chaumont, J. P. (1999). Screening of fungi for synthesis of Keratinolytic enzymes. Letters in Applied Microbiology 28:127-130.

Gautam, S.P., Bundela, P.S., Pandey. A.K., Awasthi, M.K and Sarsaiya, S. (2010). Screening of cellulolytic fungi for management of municipal solid waste. Journal of Applied Sciences in Environmental Sanitation 5(4): 391-395.

Gupta, R., Gigras, P., Mohapatra, H., Goswamy, V.K and Chauhan, B. (2003). Microbial a-amylases: a biotechnological perspective. Process Biochemistry 04:1-18.

Haki, G.D and Rakshith, S.K. (2003). Developments in industrially important thermostable enzymes; a review. Bioresource Technology. 89: 17-34.

Kathiresan, K and Manivannan, S. (2006). Alpha amylase production by Penicillium fellutanun isolated from Mangroove rhizosphere soil. African Journal of Biotechnology 3(10): 829-832.
Sci. Technol. Arts Res. J., Oct-Dec 2012, 1(4):27-32

Kirk, O., Borchert, T.V and Fuglsang, C.C. (2002). Industrial enzyme applications. Current Opinion in Biotechnology 13: 345-351.

Kundu, A.K and Das, S. (1970). Production of Amylase in Liquid Culture by a Strain of Aspergillus oryzae, Applied Microbiology 19: 598-603.

Lowry, O.H., Rosebrough, N.J., Farr, A.L and Randall, R.J. (1951). Protein measurement with the folin phenol regent. Journal of General Microbiology 131: 3017-3027.

Malloch, D. (1981). Moulds, their Isolation, Cultivation and Identification. University of Toronto Press, Toronto. Pp- 97.

McGinnis, M.R., D'Amato, R.F and Land, G.A. (1982). Pictorial Handbook of Medically Important Fungi and Aerobic Actinomycetes. Praeger Publishers, New York. Pp- 160.

Miller, G.L. (1959). Use of Dinitrosalicylic acid reagent for determination of reducing sugar. Analytical Chemistry 31: 426-248.

Mishra, B.K and Dadhich, S.K. (2010). Production of amylase and xylanase enzymes from soil fungi of Rajasthan. Journal of Advances in developmental Research 1(1): 21-23.

Moallaei, H., Zaini, F., Pihet, M., Mahmoudi, M and Hashemi, J. (2006). Isolation of Keratinophilic Fungi from Soil Samples of Forests and Farm Yards. Iranian Journal of Public Health 35(4): 62-69.

Oyeleke, S. B and Oduwole, A.A. (2009). Production of amylase by bacteria isolated from a cassava waste dumpsite in Minna, Niger state, Nigeria. African Journal of Microbiology Research 3(4): 143-146.

Pothiraj, C., Balaji, P and Eyini, M. (2006). Enhanced production of cellulases by various fungal cultures in solid state fermentation of cassava waste. African Journal of Biotechnology 5(20): 1882-1885.

Rajan, A., Kumar, D.R.S and Nair, A.J. (2011). Isolation of a novel alkaline lipase producing fungus Aspergillus fumigatus MTCC 9657 from aged and crude rice bran oiland quantification by HPTLC. International Journal of Biological Chemistry 5(2): 116-126.

Samira, M., Mohammad, R and Gholamreza, G. (2011). Carboxymethyl cellulose and filter paperase activity of new strains isolated from Persian Gulf. Microbiology Journal 1(1): 8-16.

Sathyaprabha, G., Panneerselvam, A and Muthukkumarasamy, S. (2011). Production of Cellulase and Amylase from wild and mutated fungal isolates. E-Journal of Life Sciences 1(1): 3945.

Srinivasan, M.C. (2004). Practical Mycology for Industrial Biotechnologists. Tata McGraw-Hill Publishing Company Limited, New Delhi, Pp-243.

Tiwari, K.L., Jadhav, S.K and Fatima, A. (2007). Culture condition for the production of thermostable amylase by Penicillium rugulosum. Global Journal of Biotechnology and Biochemistry 2(1): 21-24. 